\title{
TIPOLOGI DENAH RUMAH BUGIS (BOLA UGI) DI DUSUN KAJUARA KABUPATEN BONE
}

\author{
Hamka*1, Amar Rizqi Afdholy ${ }^{2}$ \\ Program Studi Arsitektur Institut Teknologi Nasional Malang 1, 2 \\ E-mail: *1hamka07@lecturer.itn.ac.id,2amarrizqi@lecturer.itn.ac.id
}

\begin{abstract}
Abstrak_ Tipologi rumah bugis secara tampilan pada umumnya terlihat sama atau identik, dengan karakter rumah panggung, namun bagaimana dengan ruang dalamnya, dalam hal ini terkait dengan denah bola ugi itu sendiri. Penelitian ini bertujuan untuk mengidentifikasi tipe denah bola ugi yang ada di Dusun Kajuara Kabupaten Bone. Metode yang digunakan adalah kualitatif deskriptif analisis dengan langkah pengumpulan data melalui pengamatan lapangan, wawancara, dan olah data. Identifikasi tipe denah bola ugi dilakukan pada beberapa objek penelitian dengan mengikuti acuan tipe standar menurut sanro bola (arsitek rumah bugis) yang telah dilakukan pada penelitian sebelumnya. Hasilnya menunjukkan bahwa keseluruhan tipe objek penelitian yang terdiri dari 3 tipe telah mengacu pada standar tipe rumah bugis yang berlaku di Dusun Kajuara, yaitu berdasarkan jumlah baris tiang alliri ke belakang pada bagian zona hunian utama. Memiliki 3 zona fungsi yang meliputi area lego-lego (bagian depan) merupakan teras rumah, area lalang mpola (bagian tengah/ dalam) merupakan zona hunian utama yang terdiri dari ruang tamu, ruang keluarga, dan kamar tidur, area annasung atau bola annasung (area servis) merupakan area dapur, ruang makan, dan tempat mencuci. Adapun perbedaan dan perubahan tata letak ruang yang tidak sesuai zona fungsi diakibatkan dari kebutuhan pemilik, sehingga pemilik memanfaatkan ruang kosong yang ada.
\end{abstract}

Kata kunci : Tipologi; Rumah Bugis ; Denah

\begin{abstract}
The bugis house form typology generally looks the same or identical, with the character of the house on stilts, but what about the inside space, in this case it is related to the bola ugi floor plan itself. This study aims to identify the type of floor plan of the bola ugi in Dusun Kajuara, Bone Regency. The method used is descriptive qualitative analysis with data collection steps through field observations, interviews, and data processing. Identification of the type of bola ugi floor plan was carried out on several research objects by following the standard type reference according to the sanro bola (bugis house architect) that had been carried out in previous studies. The results show that the overall type of research object consisting of 3 types has referred to the standard type of Bugis house that applies in Dusun Kajuara, namely based on the number of rows of alliri poles to the back in the main zone. Has 3 function zones which include the 'lego-lego' area (front area) which is the terrace of the house, the 'lalengmpola' area (middle/inside area) is the main residential zone consisting of a living room, family room, and bedroom, 'annasung' area or 'bola annasung' (service area) is the kitchen, dining room, and washing area. The differences and changes in the layout of the room that do not fit the function zone are caused by the needs of the owner, so that the owner takes advantage of the available free space..
\end{abstract}

Keywords : Typology; Bugis House; Floor Plan. 


\section{PENDAHULUAN}

Bola ugi secara harfiah diartikan sebagai rumah suku bugis, bola berarti rumah dan ugi berarti Bugis. Bola Ugi merupakan rumah tradisional suku bugis yang berfungsi sebagai tempat tinggal atau hunian bagi golongan masyarakat biasa, (Hamka 2017). Salah satu wilayah perkampungan Suku Bugis yang masih terdapat objek bola ugi adalah Dusun Kajuara Kabupaten Bone. Bola ugi ini secara fisik berupa rumah panggung yang berdiri dengan sistem struktur yang saling mengikat secara vertikal dan horizontal. Berdasarkan hasil wawancara key person terdapat tiga tipe utama bola ugi yang ada di Dusun Kajuara yaitu tipe bola 3 (tellu mpari), 5 (lima mpari), dan 7 (pitu mpari). Tipe bola 3 (tellu mpari) memiliki 3 baris tiang alliri ke belakang. Tipe bola 5 (lima mpari) memiliki 4 baris tiang alliri ke belakang. Tipe bola 7 (pitu mpari) memiliki 5 baris tiang alliri ke belakang, (Hamka, Antariksa 2015).

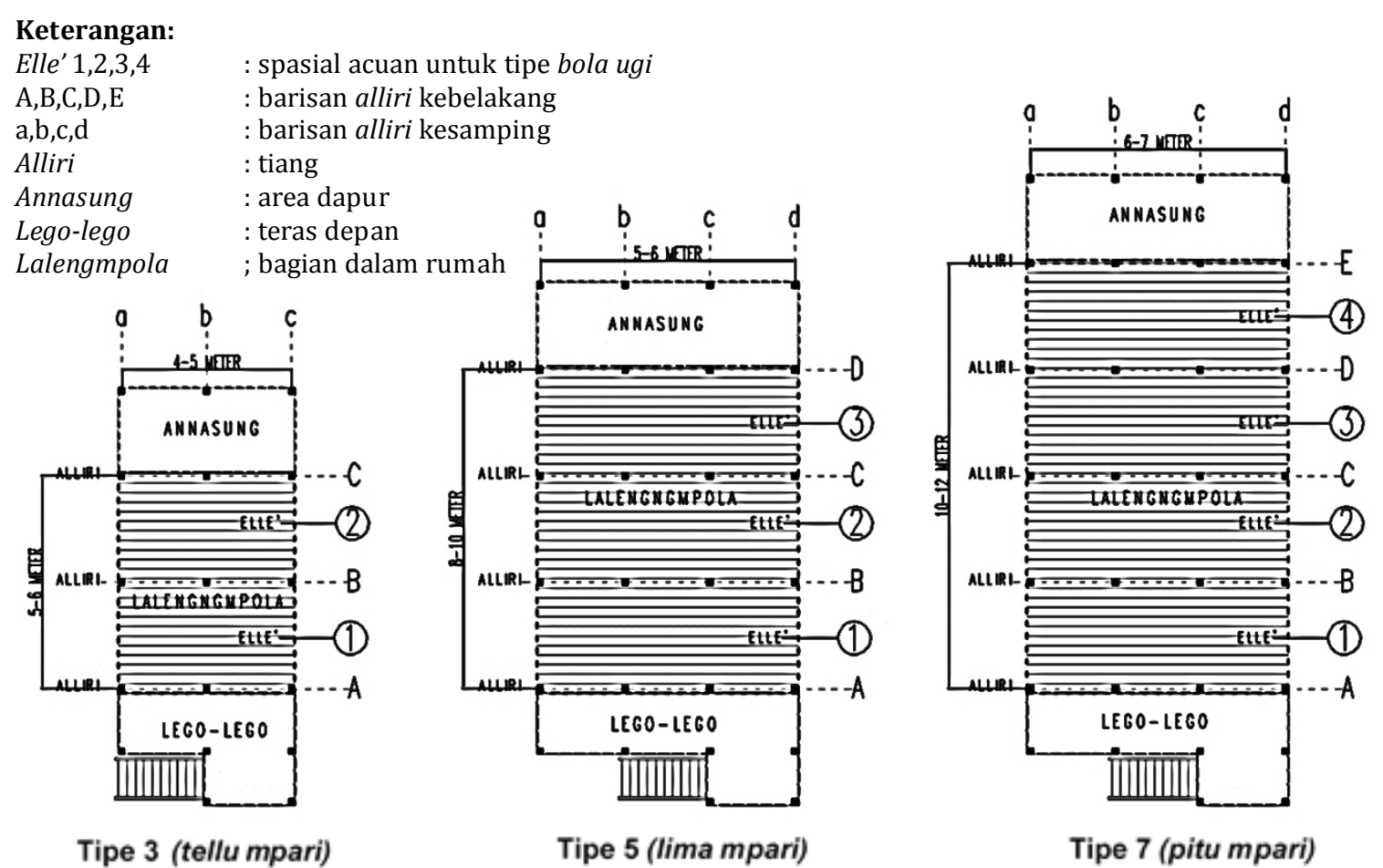

Gambar 1. Tipe Besaran Bola Ugi di Dusun Kajuara Menurut Sanro Bola Sumber: Hamka, Antariksa, Wulandari, 2015

Pada penelitian lainnya yang dilakukan oleh (Nawawi and Bola 2020) ditemukan ada 7 tipe rumah tradisional bugis berdasarkan strata sosial (bangsawan, orang terpandang, menduduki pemerintahan, menengah, dan masyarakat biasa) yang berada di Kabupaten Bone, Soppeng, dan Wajo. Pada penelitian ini akan membahas rumah bugis untuk masyarakat biasa yang berada di wilayah Dusun kajuara. Dusun Kajuara merupakan sebuah wilayah permukiman petani yang berada di Desa Mulamenre'e, Kecamatan Ulaweng, Kabupaten Bone. Dusun Kajuara berada di wilayah perbukitan dan pola pemukimannya menyebar membentuk kelompok-kelompok permukiman yang terhubung secara linier oleh sirkulasi jalan desa yang melintasi desa. Kelompok permukiman di Dusun Kajuara masing-masing memiliki karakteristik orientasi rumah yang juga 
berpengaruh pada pola tata letak ruang hunian bola ugi di Dusun Kajuara, (Hamka, Antariksa, Wulandari 2015).

Tipologi merupakan ilmu yang mempelajari pengelompokan objek sebagai model yang dilihat dari kesamaan bentuk atau struktur sebuah benda. Berdasarkan sejarah perkembangannya teori tipologi dalam arsitektur berkembang 3 konsep yaitu pertama dikembangkan dari filosofi rasionalis Pencerahan, yang kedua berkaitan dengan ideologi modernis dan terakhir dengan NeoRasionalisme setelah 1960-an, (Güney 2007). Dalam kontek arsitektur, tipologi dipahami sebagai kegiatan yang berhubungan dengan klasifikasi atau pengelompokan objek arsitektur terkait kesamaan ciri dengan karakteristik yang tetap dan konstan, diantaranya kesamaan bentuk dasar, sifat dasar, dan tema, (Damayanti, Nugroho, and Santosa 2017). Tipologi adalah suatu ilmu yang mempelajari segala sesuatu tentang tipe dengan cara menelusuri elemen-elemen pembentuk suatu sistem objek bangunan atau arsitektur, (Nurtantyo and Wikantiyoso 2018). Tipologi merupakan upaya untuk mengkelaskan, mengelompokkan atau mengklasifikasikan berdasar aspek, Fungsi (meliputi penggunaan ruang, struktural, simbolis, dan lain-lain); Geometrik (meliputi bentuk, prinsip tatanan, dan lain-lain); dan Langgam (meliputi periode, lokasi , politik atau kekuasaan, etnik dan budaya, dan lain-lain) Sulistijowati dalam (Ramadanta 2010).

Penelitian terdahulu terkait tipologi rumah bugis sebagian besar terfokus pada aspek geometrik/ langgam, seperti fasade, pintu, jendela, atap dan ornament, sehingga menjadi sebuah hal yang baru jika diteliti dari aspek tata ruangnya. Berdasarkan pada hasil observasi awal menunjukan bahwa ketiga tipe bola ugi di Dusun Kajuara hanya berdasarkan pada jumlah baris tiang rumah, namun tidak pada pola tata letak ruangnya. Maka pada penelitian ini penulis akan membahas tipologi denah rumah bugis (bola ugi). Tujuannya adalah untuk mengetahui bentuk, zona fungsi, jenis ruang, pola susunan dan tata letak denah pada masing-masing tipe objek yang diteliti. Hasilnya kemudian dikelompokan berdasarkan aspek fungsi penggunaan ruang, kesamaan ciri denah pada masing-masing objek penelitian.

\section{METODE}

Penelitian ini menggunakan jenis penelitian lapangan (field research) dengan metode penelitian kualitatif deskriptif analisis (descriptive research). Karakteristik utama penelitian kualitatif berasal dari latar belakang alami/kenyataan di masyarakat, menggunakan metode kualitatif dengan langkah pengumpulan data melalui pengamatan lapangan, wawancara, dan olah data. Penyajian dan analisis data pada penelitian kualitatif dilakukan secara naratif, (Subandi 2011). Variabel analisis data yang digunakan untuk mengkaji tipologi denah ruang rumah tradisional suku bugis bola ugi di Dusun Kajuara dapat dilakukan dengan mengkaji aspek jenis ruang, zona, fungsi, tata ruang dan sifat ruang, (Samra, Faradika, and Salat 2020), (Ratna Wijayanti, Wiwik Setyaningsih 2019), (Agustin et al. 2021). Kriteria pemilihan objek penelitian berdasarkan tipe bola ugi yang ada di Dusun Kajuara adalah menggunakan teknik kriteria inklusi, yaitu kriteria penerimaan. Kriteria inklusi berdasarkan pada tipe bola ugi yang ada di Dusun Kajuara menurut sanro bola (Gambar 1) yaitu tipe bola 3 mpari, tipe bola 5 mpari, tipe bola 7 mpari. Tipe yang ada akan diterima sebagai perwakilan objek penelitian, dan objek dari kriteria tersebut akan mewakili situasi objek penelitian yang ada di dusun ini. 
Berikut ini adalah tahapan penelitian (Gambar 2) dan objek penelitian yang akan diamati dalam penelitian ini; (1). Tipe bola ugi 7 mpari; (a). Objek 7a (rumah Puang Kamare), (b). Objek 7b (rumah Nene Dali), (c). Objek 7c (rumah Puang Nusi). (2). Tipe bola ugi 5 mpari; (a). Objek 5a (rumah Puang Suki), (b). Objek 5b (rumah Puang Tanni), (c). Objek 5c (rumah Hj. Walina). (3). Tipe bola ugi 3 mpari; (a). Objek 3a (rumah H. Daga), (b). Objek 3b (rumah Puang Pudding), (c). Objek 3c (rumah Puang Pallu). Peta lokasi persebaran objek yang diteliti sebagai berikut, (Gambar 3).

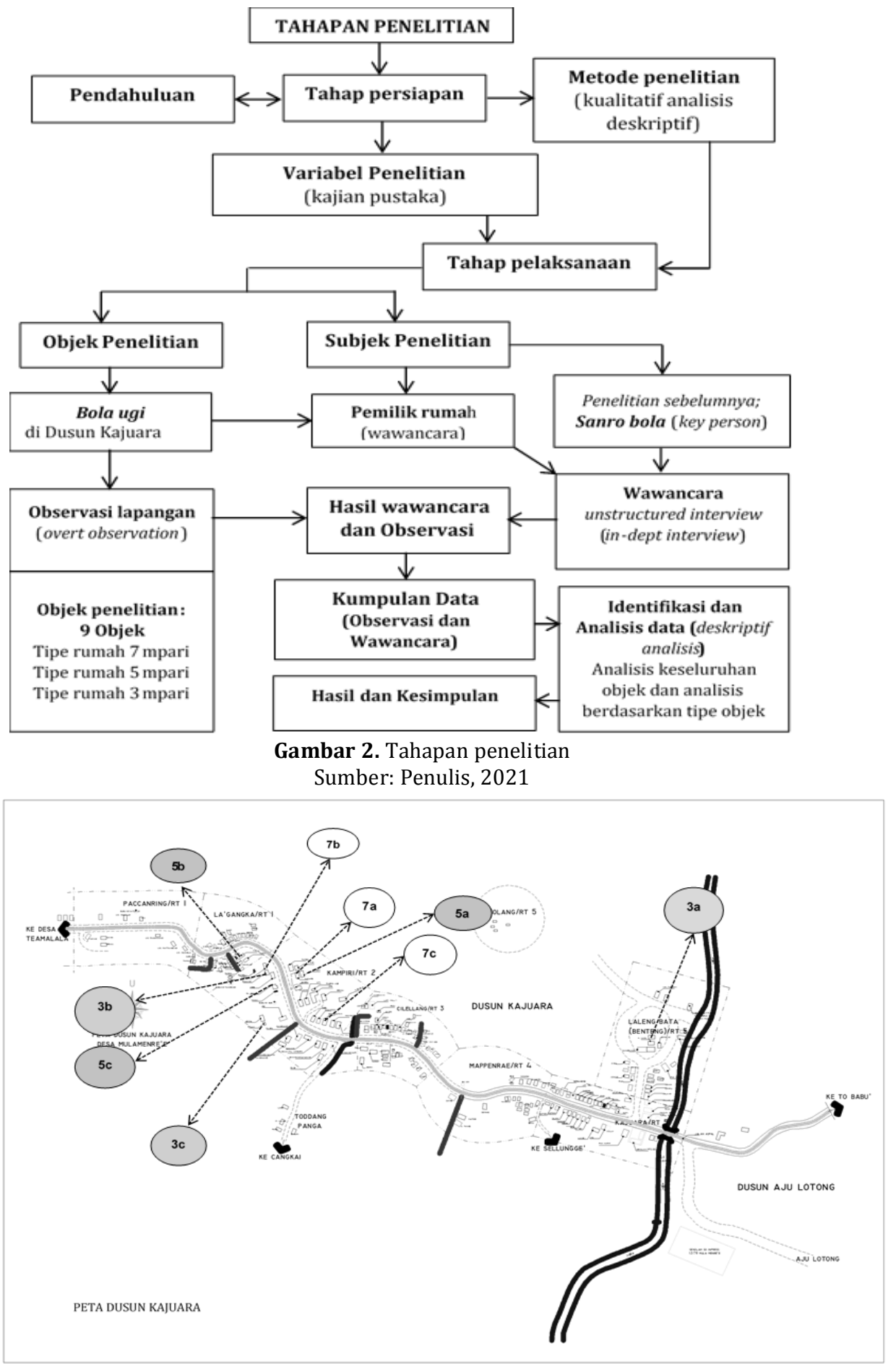

Gambar 3. Peta lokasi persebaran objek penelitian di Dusun Kajuara Sumber: Penulis, 2021 


\section{HASIL DAN PEMBAHASAN}

\section{A. Tipologi Tipe 7 (Pitu Mpari)}

Tipe bola 7 mpari yang dijadikan sebagai objek penelitian dalam pembahasan ini adalah sebanyak 3 objek, yaitu (a). Objek 7a (rumah Puang Kamare), (b). Objek 7b (rumah Nenek Dali), (c). Objek 7c (rumah Puang Nusi). Berikut ini foto dan denah objek penelitian tipe bola 7 mpari (Gambar 4 dan 5).

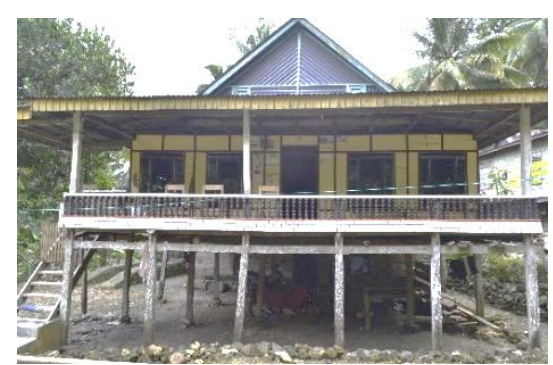

Objek 7a

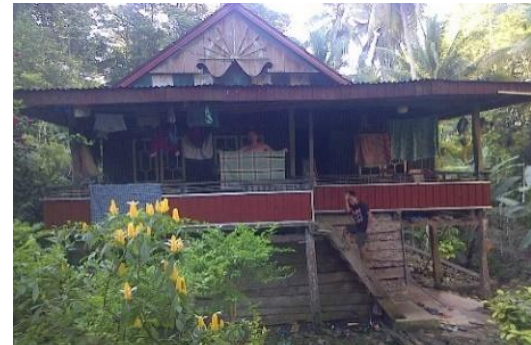

Objek 7b

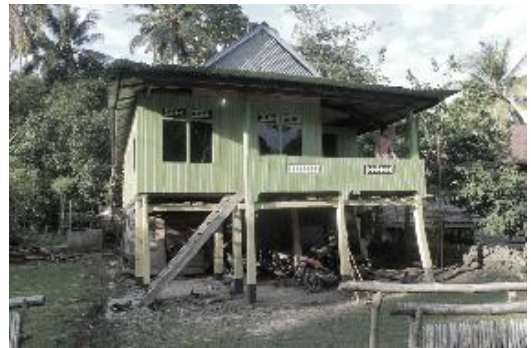

Objek 7c

Gambar 4. Objek penelitian tipe 7 mpari Sumber: Penulis, 2021

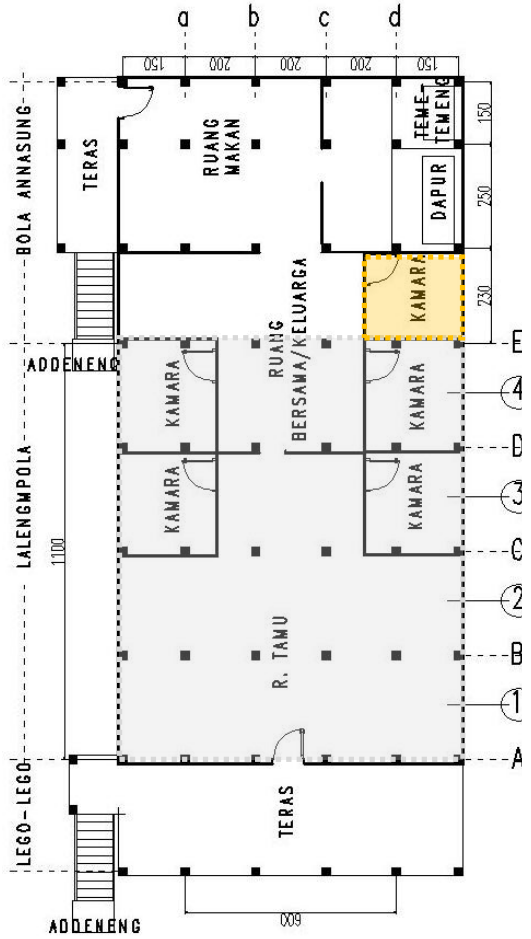

Objek 7a

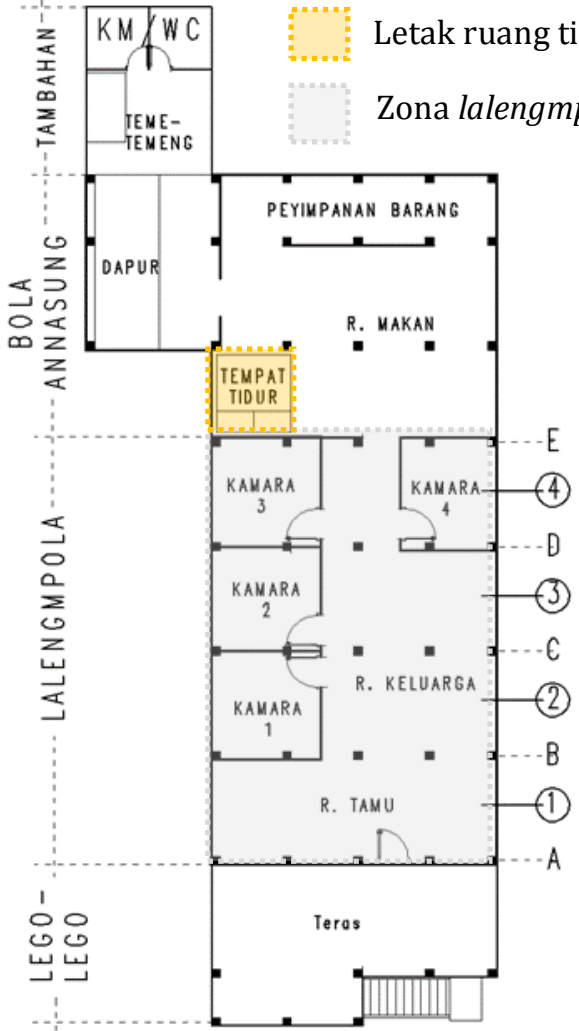

Objek 7b

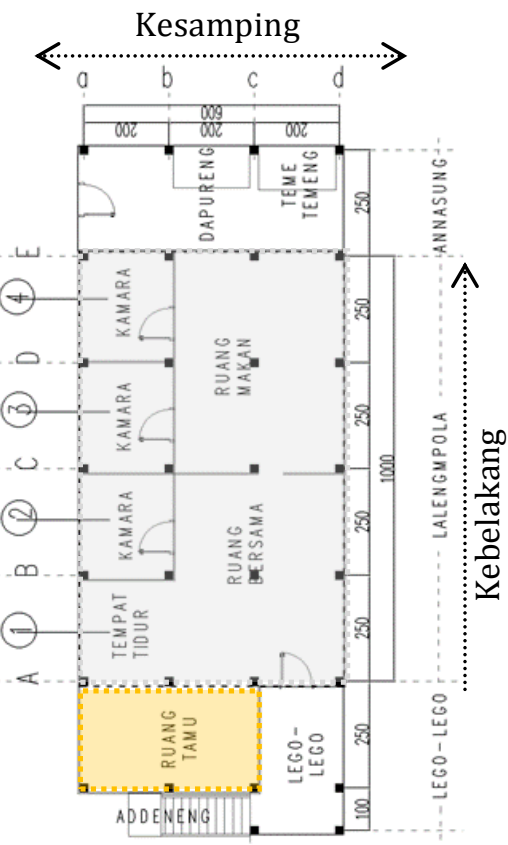

Objek 7c

Gambar 5. Denah objek penelitian tipe 7 mpari Sumber: Penulis, 2021 
Ketiga objek penelitian merupakan tipe bola 7 pitu mpari jika dilihat dari aturan memiliki 5 baris tiang alliri ke belakang pada bagian laleng pola (bagian tengah/ dalam rumah) atau memiliki jumlah 4 spasial ruang elle' diantara tiang alliri. Jumlah alliri kesamping standarnya berjumlah 4 tiang alliri seperti pada gambar objek 7c. Namun pada objek 7b ditambahkan ruang tambahan pada sisi kanan, sedangkan objek 7a terdapat ruang tambahan pada kedua sisi. Akibatnya ketiga objek memiliki luasan ruang yang berbeda dan lebar rumah yang berbeda. Ketiga objek tipe 7 mpari ini juga dibagi dalam 3 zona atau area yaitu area lego-lego atau teras rumah, bersifat publik dan berfungsi sebagai area untuk menerima tamu ataupun sebagai area berkumpul dan bersantai. Area lalang mpola (bagian dalam rumah) didalamnya terdapat ruang tamu/ ruang keluarga/ ruang bersama dan kamar tidur (kamara). Area bola annasung (rumah dapur) didalamnya terdapat ruang makan, dapur (dapureng) dan area mencuci (teme-temeng).

Ketiga objek tersebut memiliki perbedaan dari segi besaran/ luasan ruang dan juga tata letak beberapa ruang. Pada objek 7c terjadi pengalihan fungsi sebagian area teras menjadi ruang tamu tertutup pada area lego-lego (teras rumah), ruang makan diletakkan pada bagian laleng pola bukan pada area annasung (dapur), akibat dari tidak adanya bola annasung (rumah dapur) dan keterbatasan luasan yang terdapat pada area dapur. Area dapur objek 7c memiliki luasan ruang yang jauh lebih kecil dibanding kedua objek yang lainnya karena objek 7a dan 7b memiliki penambahan area bola annasung (rumah dapur). Letak kamar tidur (kamara) pada objek 7a dan 7b berada di sisi kiri dan kanan bagian laleng pola berbeda dengan objek 7c yang kamar tidurnya hanya terdapat pada satu sisi saja. Semakin besar/ luas rumah biasanya semakin banyak pula penghuninya, sehingga membutuhkan lebih banyak kamar tidur di dalamnya.

\section{B. Tipologi Tipe 5 (Lima Mpari)}

Tipe bola 5 mpari yang dijadikan sebagai objek penelitian dalam pembahasan ini adalah sebanyak 3 objek, yaitu (a). Objek 5a (rumah Puang Suki), (b). Objek 5b (rumah Puang Tanni), (c). Objek 5c (rumah Hj. Walina). Berikut ini foto dan denah objek penelitian tipe bola 5 mpari (Gambar 6 dan 7).

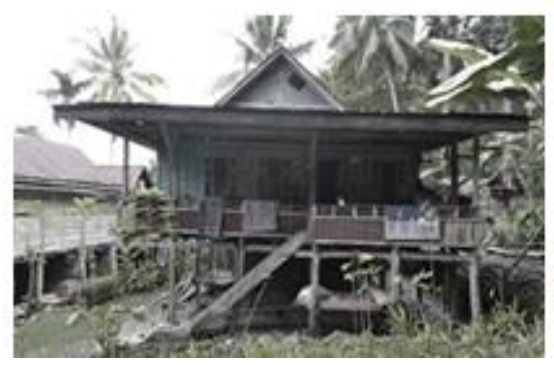

Objek 7a

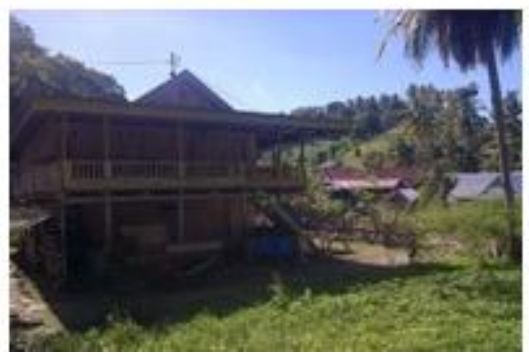

Objek5b

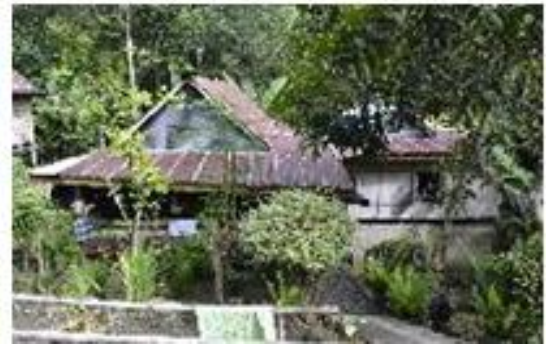

Objek5c

Gambar 6. Objek penelitian tipe 5 mpari Sumber: Penulis, 2021 


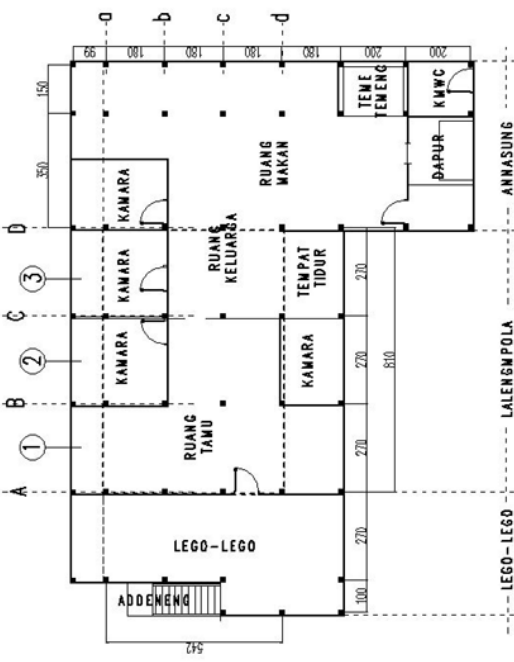

Objek 5a

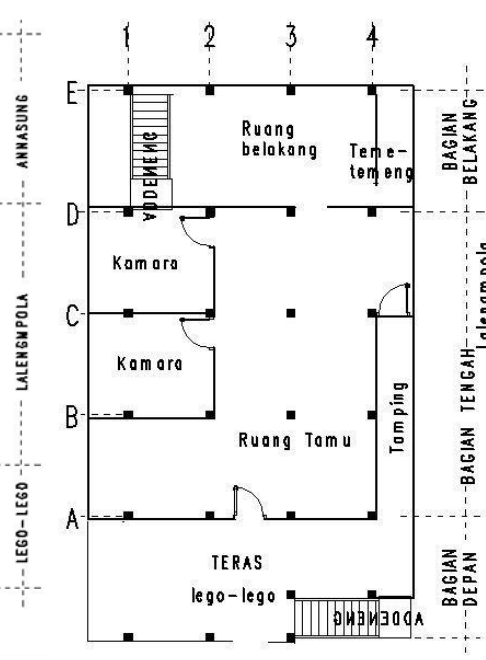

Objek $5 b$

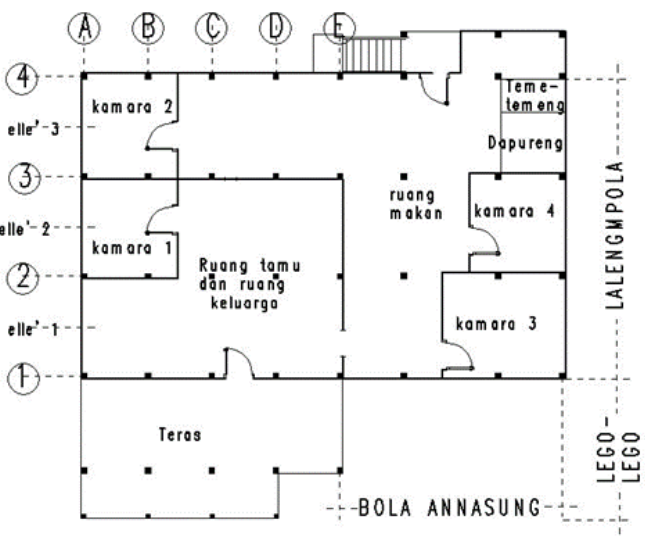

Objek 5c

Gambar 7. Denah Objek Penelitian Tipe 5 Mpari

Sumber: Penulis, 2021

Ketiga objek ini sama-sama memiliki 4 baris tiang alliri ke belakang pada bagian laleng pola (bagian dalam/ tengah rumah) memiliki jumlah 3 spasial ruang elle' diantara tiang alliri. Rumah tipe 5 mpari ini acuan standarnya memiliki 4 baris tiang alliri ke samping, namun ketiga objek tipe 5 mpari ini masing-masing menambahkan spasial tambahan disalah satu atau kedua sisinya. Objek $5 \mathrm{a}$ dan $5 \mathrm{~b}$ terdapat ruang tambahan yang dari segi struktural menggunakan sistem kantilever. Ketiga objek juga memiliki 3 zona yaitu lego-lego teras rumah, laleng pola bagian tengah/ dalam rumah, dan area bola annasung (rumah dapur). Keseluruhan zona tersebut memiliki jenis ruang, sifat dan fungsi yang sama dengan apa yang ada pada objek tipe 7 mpari, tetapi juga memiliki beberapa perbedaan dari segi tata letak ruang dan perubahan fungsi ruang.

Perubahan fungsi pertama dapat kita lihat pada objek $5 a$ dan $5 \mathrm{c}$, yaitu terdapat kamar tidur yang diletakkan pada bagian bola annasung (rumah dapur) yang seharusnya tidak difungsikan sebagai area kamar tidur. Objek 5 tidak memiliki dapur pada bagian belakang karena pemilik rumah memindahkannya di lantai 1 pada bagian kolong rumah. Letak bola annasung objek 5c juga berbeda dengan yang lainnya, yaitu berada disamping rumah utama, bukan pada bagian belakang, karena pada bagian rumah terdapat saluran air yang melintas dan tidak boleh berada dibawah rumah, sehingga posisinya dipindahkan pada bagian samping. Tipe 5 mpari ini memiliki luasan dan pola tata letak yang berbeda namun memenuhi syarat tipe bola ugi 5 mpari.

\section{Tipologi Tipe 3 (Tellu Mpari)}

Tipe bola 3 mpari yang dijadikan sebagai objek penelitian dalam pembahasan ini adalah sebanyak 3 objek, yaitu (a). Objek 3a rumah Puang H. Daga, (b). Objek 3b rumah Puang Pudding, (c). Objek 3c rumah Puang Pallu. Berikut ini foto dan denah objek penelitian tipe bola 3 mpari (Gambar 8 dan 9). 


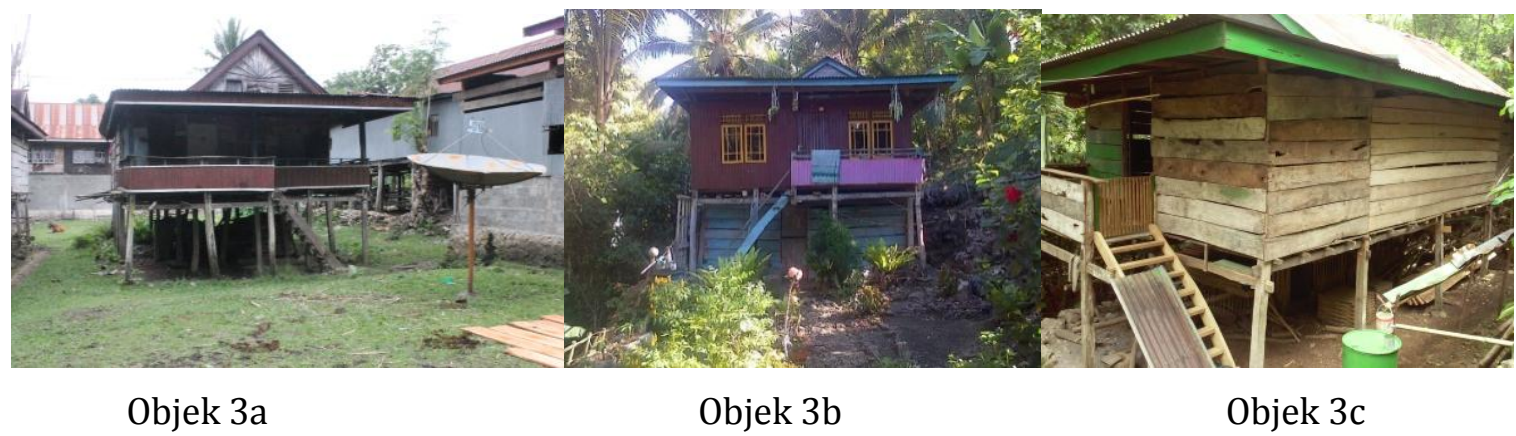

Gambar 8. Objek penelitian tipe 3 mpari Sumber: Penulis, 2021

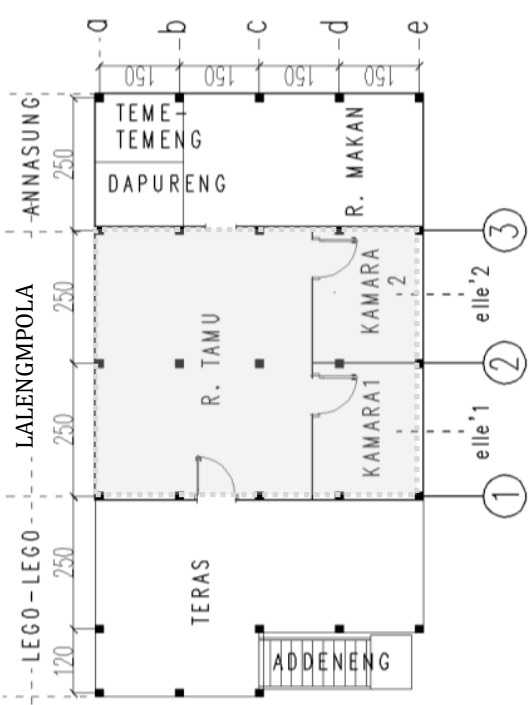

Objek 3a

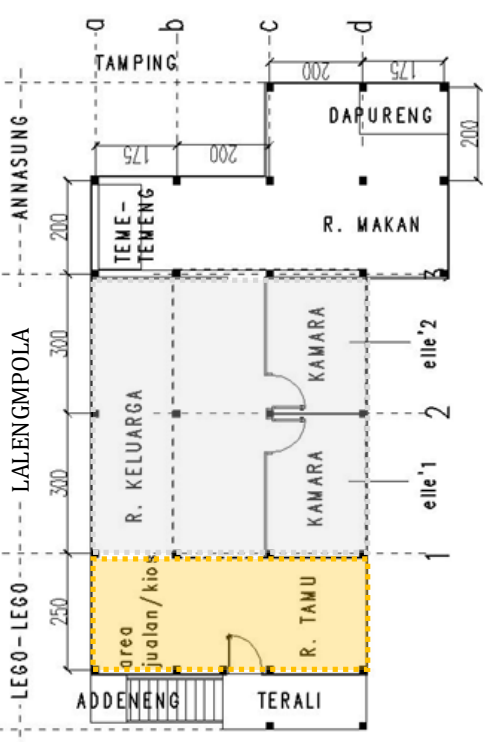

Objek 3b

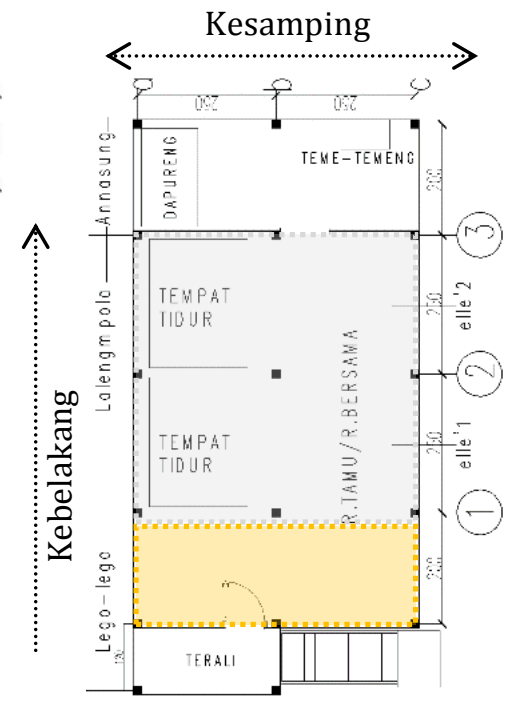

Objek 3c

Letak ruang tidak sesuai dengan zona fungsi

Zona lalengmpola sebagai acuan tipe rumah

Gambar 9. Denah objek tipe bola 3 mpari Sumber: Penulis, 2021

Objek tipe bola 3 mpari juga mengacu pada aturan tipologi besaran rumah tipe 3 mpari yaitu memiliki 3 baris tiang alliri kebelakang atau 2 elle' pada badan bagian laleng pola. Jumlah tiang alliri kesamping masing-masing objek memiliki jumlah yang berbeda, objek 3a memiliki 5 baris alliri, objek 3b memiliki 4 baris dan objek 3c memiliki 3 baris. Aspek zoning ketiga objek tipe 3 mpari memiliki pembagian zona yang sama dengan objek tipe 7 dan 5 yaitu memiliki area lego-lego, laleng pola dan annasung. Area lego-lego (teras rumah) objek $3 \mathrm{~b}$ dan $3 \mathrm{c}$ mengalami perubahan fungsi menjadi bagian dari area laleng pola dan difungsikan sebagai ruang tamu, sehingga menyisakan sedikit area teras pada bagian depan rumah. Perubahan fungsi tersebut terjadi akibat kebutuhan ruang utama meningkat sedangkan lahan yang tersedia pada area laleng pola terbatas, sehingga pemilik memanfaatkan sebagian besar area lego-lego (teras rumah) sebagai area ruang dalam. Meskipun ketiga objek ini sesuai dengan syarat tipologi rumah tipe 3 mpari, namun dari segi luasan dan pola tata letak ruangnya berbeda-beda. 


\section{Diskusi}

Berdasarkan pada hasil uraian masing-masing objek penelitian berdasarkan tipe bola ugi yang ada di Dusun Kajuara Kabupaten Bone, maka berikut ini rangkuman tipologi tipe bola ugi di Dusun Kajuara berdasarkan acuan jumlah tiang alliri, pembagian zoning fungsi dan jenis ruang (Tabel 1).

Table 1. Uraian tipologi rumah bugis (bola ugi) di Dusun Kajuara

\begin{tabular}{|c|c|c|c|c|c|}
\hline No & Tipe & $\begin{array}{c}\text { Jumlah tiang } \\
\text { alliri ke } \\
\text { belakang }\end{array}$ & $\begin{array}{c}\text { Jumlah } \\
\text { tiang alliri } \\
\text { ke samping }\end{array}$ & Zoning & Fungsi dan Jenis ruang \\
\hline & $\begin{array}{l}\text { Objek } \\
\text { yang } \\
\text { diteliti }\end{array}$ & $\begin{array}{l}\text { Sebagai acuan } \\
\text { untuk } \\
\text { mengidentifik } \\
\text { asi tipe bola } \\
\text { ugi di Dusun } \\
\text { Kajuara }\end{array}$ & $\begin{array}{l}\text { Tidak ada } \\
\text { aturan } \\
\text { khusus }\end{array}$ & $\begin{array}{l}\text { Memiliki } 3 \\
\text { area yaitu } \\
\text { bagian lego- } \\
\quad \text { lego, } \\
\text { lalengmpola, } \\
\text { annasung }\end{array}$ & $\begin{array}{l}\text { Lego-lego fungsi publik (teras rumah), } \\
\text { lalengmpola fungsi utama hunian } \\
\text { (ruang tamu/keluarga, kamar tidur), } \\
\text { annasung fungsi servis (dapur, ruang } \\
\text { makan dan area mencuci) }\end{array}$ \\
\hline 1 & 7 mpari & 5 baris & - & & \\
\hline $\mathbf{a}$ & Objek 7a & $\checkmark$ & 6 baris & $\checkmark$ & $\checkmark$ \\
\hline $\mathbf{b}$ & Objek 7b & $\checkmark$ & 5 baris & $\checkmark$ & $\checkmark$ \\
\hline c & Objek 7c & $\checkmark$ & 4 baris & $\checkmark$ & $\checkmark$ \\
\hline 2 & 5 mpari & 4 baris & - & & \\
\hline $\mathbf{a}$ & Objek 5a & $\checkmark$ & 5 baris & $\checkmark$ & $\checkmark$ \\
\hline $\mathbf{b}$ & Objek 5b & $\checkmark$ & 5 baris & $\checkmark$ & $\checkmark$ \\
\hline c & Objek 5c & $\checkmark$ & 4 baris & $\checkmark$ & $\checkmark$ \\
\hline 3 & 3 mpari & 3 baris & - & & \\
\hline $\mathbf{a}$ & Objek 3a & $\checkmark$ & 5 baris & $\checkmark$ & $\checkmark$ \\
\hline $\mathbf{b}$ & Objek 3b & $\checkmark$ & 4 baris & $\checkmark$ & $\checkmark$ \\
\hline$\overline{\mathbf{c}}$ & Objek 3c & $\sqrt{ }$ & 3 baris & $\bar{\checkmark}$ & $\checkmark$ \\
\hline
\end{tabular}

Sumber: Penulis, 2021

Tabel 1 menunjukkan bahwa aspek jumlah alliri ke belakang pada masing-masing objek telah sesuai dengan acuan untuk menentukan tipe bola ugi. Jumlah tiang alliri ke samping tidak ada aturan khusus, namun dari objek yang diteliti menunjukkan bahwa, jumlah tiang alliri ke samping untuk tipe 7 mpari terdiri dari 4-6 baris, tipe 5 mpari terdiri dari 4-5 baris, dan tipe 3 terdiri dari 3-5 baris. Keseluruhan objek penelitian telah dibagi dalam 3 zona fungsi dan jenis ruang yang sama, namun memiliki luasan atau besaran ruang yang berbeda serta tata letak yang berbeda juga. Berdasarkan hasil wawancara terkait tata letak ruang yang berbeda tersebut diakibatkan dari berbagai pertimbangan seperti orientasi rumah, topografi dan eksisting rumah, serta aspek kepercayaan atau mitologi. Adapun ruang-ruang yang tidak diletakkan sesuai dengan zoning fungsinya misalkan meletakkan kamar tidur pada area annasung atau dapur seperti pada objek $7 \mathrm{a}, 7 \mathrm{~b}, 5 \mathrm{a}, 5 \mathrm{c}$, dan membuat ruang tamu tertutup di area lego-lego seperti pada objek 7c, 3b, dan 3c. Hal tersebut terjadi akibat dari meningkatnya kebutuhan ruang pemilik, sehingga ruang yang masih kosong dimanfaatkan sesuai dengan kebutuhan.

Area dapur pada bola ugi di Dusun Kajuara ditemukan ada 2 jenis, yaitu annasung dan bola annasung. Keduanya memiliki fungsi, jenis ruang dan sifat yang sama. Perbedaannya dari 
segi fisik yaitu area annasung biasanya memiliki luasan yang lebih kecil dibanding bola annasung, area annasung hanya berupa ruang tambahan yang menempel pada bagian belakang rumah utama, sedangkan bola annasung secara fisik memiliki atap dan rakkeang (ruang penyimpanan pada atap) yang letaknya bisa dibagian belakang atau disamping rumah utama. Rumah yang memiliki 2 atap yang berbentuk segitiga maka salah satunya merupakan bola annasung (rumah khusus untuk masak-memasak), sedangkan rumah yang hanya memiliki 1 atap segitiga, maka biasanya hanya menyediakan area annasung (dapur pada bagian belakang rumah). Pada kasus objek penelitian ini, rumah denah rumah yang memiliki bola annasung (rumah dapur) adalah objek 7a, 7b, 5a, dan 5c, sisanya objek 7c, 5b, 3a, 3b, dan 3c hanya memiliki area dapur saja (Gambar 10).

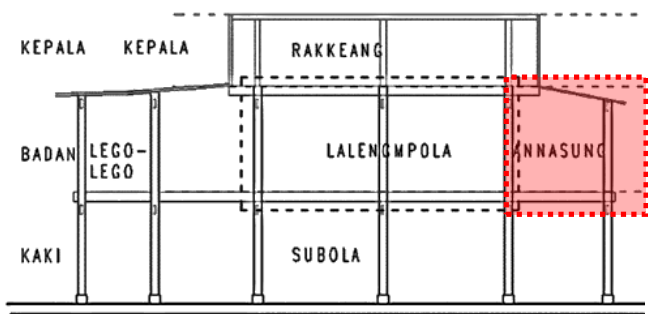

Area annasung/dapur menyatu dengan rumah utama

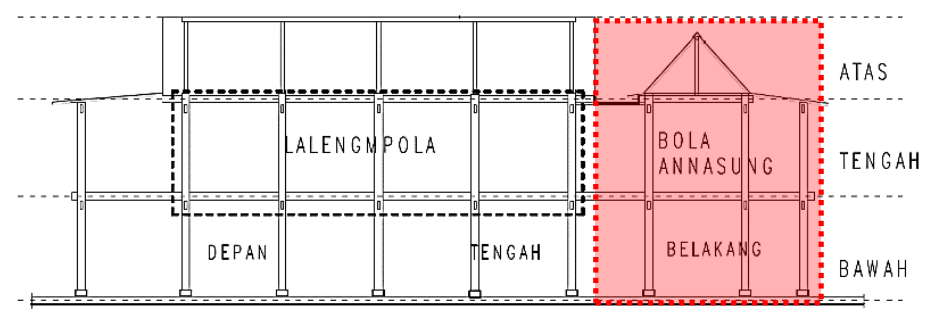

Bola annasung/rumah dapur terhubung dengan rumah utama dan memiliki atap sendiri

Gambar 10. Perbedaan area annasung (dapur) dan bola annasung (rumah dapur) Sumber: Penulis, 2021

\section{KESIMPULAN}

Berdasarkan pada hasil pembahasan ditemukan bahwa keseluruhan tipe objek penelitian telah mengacu pada standar tipe rumah bugis yang berlaku di Dusun Kajuara yaitu berdasarkan jumlah baris tiang alliri ke belakang. Jumlah alliri ke samping lebih bervariasi, untuk tipe 7 mpari terdiri dari 4-6 baris, tipe 5 mpari terdiri dari 4-5 baris, dan tipe 3 terdiri dari 3-5 baris. Aspek zoning kesemuanya dibagi dalam 3 bagian yaitu a). area lego-lego (bagian depan) bersifat publik, merupakan teras rumah, b). area lalang mpola (bagian tengah/ dalam) bersifat semi publik dan private, merupakan area ruang tamu, ruang keluarga, dan kamar tidur, c). area dapur ditemukan ada 2 jenis yaitu annasung dan bola annasung sebagai area servis yang bersifat private namun dalam beberapa kondisi dapat menjadi area semi publik bagi tetangga rumah. Pada area ini biasanya terdiri dari area dapur, ruang makan, dan tempat mencuci. Terjadi beberapa perubahan tata letak ruang akibat dari kebutuhan pemilik rumah sehingga memanfaatkan ruang kosong yang ada. Secara umum tipologi denah rumah bugis / bola ugi di Dusun Kajuara jika ditinjau besaran ruangnya tidak ada yang sama, namun dari segi bentuk denah semuanya berbentuk persegi panjang. Penelitian ini masih terfokus pada identifikasi dan analisis tipe bola ugi berdasarkan acuan yang diberikan oleh sanro bola berdasarkan variabel jenis ruang, zona, fungsi, tata ruang dan sifat ruang, sehingga belum detail membahas alasan tata letak ruangan, khususnya letak ka mar, dapur dan tempat cucian, maupun hal-hal terkait sirkulasi, dimensi ruang, letak bukaan dan isi ruangan. Maka, hal yang belum dibahas tersebut dapat menjadi topik pembahasan objek rumah bugis di Dusun Kajuara pada tulisan selanjutnya. 


\section{DAFTAR REFERENSI}

Agustin, Dyan, Mochamad Hamdan M, Renada Trifirdausi Nabila, and Ahmad Ikhbar Z. 2021. "Tipologi Ruang Dalam Rumah Lamin Berdasarkan Sistem Adat Pada Masyarakat Suku Dayak" 11 (1): 33-40.

Damayanti, Fifi, Agung Murti Nugroho, and Herry Santosa. 2017. "Tipologi Rumah Jawa Di Kawasan Perdesaan Sumber Polaman Lawang." Jurnal Reka Buana Volume 2 No 1, September 2016 - Februari 20172 (1): 56-73.

Güney, Yasemin Đ. 2007. “Type and Typology in Architectural Discourse.” BAU FBE Dergisi 9 (1): 3-18.

Hamka, Antariksa, Wulandari, Lisa Dwi. 2015. "KARAKTERISTIK ORIENTASI RUMAH TRADISIONAL BUGIS (BOLA $\begin{array}{llllll}\text { UGI }) & \text { DI } & \text { DUSUN } & \text { KAJUARA }\end{array}$ https://doi.org/http://dx.doi.org/10.26418/lantang.v2i2.13832.

Hamka, Antariksa, Lisa Dwi Wulandari. 2015. "HIRARKI SPASIAL BOLA UGI DI DUSUN KAJUARA KABUPATEN BONE SULAWESI SELATAN." Arsitektur E-Journal 8 (1): 21-37. https://core.ac.uk/reader/198116590.

Hamka. 2017. "Nilai Kenusantaraan Arsitektur Bola Ugi Menurut Sanro Bola Di Dusun Kajuara Kabupaten Bone." ATRIUM Jurnal Arsitektur 3 (1): 59-68. https://doi.org/10.21460/atrium.v3i1.66.

Nawawi, Nurnaningsih, and Panrita Bola. 2020. "Teknologi Membangun Rumah Bugis Menurut Panrita Bola Ugi." Jurnal Teknosains 14 (1): 44-52.

Nurtantyo, and Wikantiyoso. 2018. "Tipologi Pintu Dan Jendela Pada Fasad Rumah Di Kampung Biru Arema Kelurahan Kiduldalem." LOCAL WISDOM 10 (2): 91-110.

Ramadanta. 2010. "KAJIAN TIPOLOGI DALAM PEMBENTUKAN KARAKTER VISUAL DAN STRUKTUR KAWASAN (Studi Kasus: Kawasan Ijen, Malang)." SMARTek 8 (2): 130-42.

Ratna Wijayanti, Wiwik Setyaningsih, Avi Marlina. 2019. "Tipologi Pola Ruang." Jurnal SENTHONG, no. 2016: 71322.

Samra, Boby, Rico Faradika, and Junaedi Salat. 2020. “TIPOLOGI RUMAH TRADISIONAL MELAYU HILIR SUNGAI SIAK." In , edited by SH Suparmi, SE Dwi Prihatiningsih, M.Kom Ir. Gatot Budi Santoso, SE Tjutju R. Suprapto, and SH Sardiyanto, 1-11. Jakarta: Lembaga Penelitian Universitas Trisakti.

Subandi. 2011. "Deskripsi Kualitatif Sebagai Satu Metode Dalam Penelitian Pertunjukan." Harmonia: Journal of Arts Research and Education 11 (2): 173-79. https://doi.org/10.15294/harmonia.v11i2.2210. 